\title{
Geographical analysis of vegetation structure and sightings for four large bird species in the Kruger National Park, South Africa
}

\author{
A. C. KEMP, G. A. BENN and K. S. BEGG
}

\section{Summary}

The extensive spatial organization of many large-bird populations is difficult to assess. We used a geographic information system to correlate vegetation structure with random sightings for four large bird species that occur throughout the $20,000 \mathrm{~km}^{2}$ Kruger National Park (KNP), South Africa. Vegetation structure was assessed visually during 1991-1992 for the 1093 2.5'-quadrats that cover the KNP. Sightings were made during 1991-1994 of Kori Bustard Ardeotis kori, Martial Eagle Polemaetus bellicosus, Lappet-faced Vulture Torgos tracheliotus and Southern Ground Hornbill Bucorous leadbeateri, and their nest sites. As a control, comparative data on ground hornbills were also available from annual aerial censuses during 1982-1994, and from records of nest sites during 1966-1996. Each species had its highest positive correlation with a different set of vegetation categories, ranging in value from the hornbill (1.13) and vulture (1.15) up to the eagle (1.32) and bustard (1.49). Nest sites had higher correlations (hornbill 1.65, vulture 2.85) than records of free-living birds. The same vegetation categories that had the highest correlations with random sightings of ground hornbills and their nests also had the highest correlations with the more extensive and systematic data from aerial census and long-term nest records. Our method of correlating vegetation structure with random data is predictive, testable and has application to the conservation management of other sparsely distributed species.

\section{Introduction}

Scale is an important component in any ecological study, especially for large, widely-dispersed and long-lived organisms (May 1994). One way of assessing the dispersion of such organisms is by correlation with environmental variables. This has been done for a wide range of plants and animals, including birds (Miller et al. 1989), and has been facilitated by geographic information system (GIS) technology. However, most studies have been done at either a fine local scale or at a broad national scale, rarely at the intermediate scale of this study (Hurford et al. 1996).

Our study of large birds in the Kruger National Park (KNP), the Big Six Project (Kemp 1992, Kemp et al. 1991), attempted to estimate their relative abundance and habitat associations. The method employed had to be practical at the spatial scale of an area as extensive as Wales or Israel, at the temporal scale of our 3-year study period, and with a maximum of two field observers. 
Several large bird species occur throughout the KNP but most are unevenly distributed, exist naturally at low densities, have widely spaced breeding sites, and include non-territorial non-breeding components in their populations (Kemp 1988, Kemp and Kemp 1974, 1980). It is difficult to assess their spatial organization over such sparse and irregular distributions. Most species are so thinly and widely dispersed that standard census methods are impractical or laborious (Watson 1990). Their extensive home ranges also make it difficult to record habitat parameters at an appropriate scale with sufficient resolution.

In this study we correlated a subjective visual assessment of vegetation structure (Kemp et al. 1997) with random records of each species and their nests. This was facilitated by using a GIS for the display and analysis of data. The results indicated that each species had different vegetation associations, including for their nest sites, which could be used to predict areas of highest probability of occurrence. This also indicated habitat preferences and areas most important for their conservation.

\section{Study area}

The study was conducted in the $20,000 \mathrm{~km}^{2} \mathrm{KNP}$, north-eastern South Africa (within $22-26^{\circ} \mathrm{S}, 31-32^{\circ} \mathrm{E}$ ). The general landscape is of undulating granitic and basaltic soils covered by various forms of wooded savanna (Gertenbach 1983). Most of the KNP is less than $500 \mathrm{~m}$ a.s.l. and receives an average annual summer rainfall ranging from $750 \mathrm{~mm}$ in the south-west to $450 \mathrm{~mm}$ in the north-east (Gertenbach 1980). The KNP is dissected by a few large perennial rivers and by numerous seasonal watercourses. Various features and habitats in the KNP have already been described and mapped, including our assessment of vegetation structure (Kemp et al. 1997).

\section{Methods}

All sight records for Kori Bustard Ardeotis kori, Martial Eagle Polemaetus bellicosus, Lappet-faced Vulture Torgos tracheliotus and Southern Ground Hornbill Bucorvus leadbeateri, and their nest sites, were recorded during general research and travel within the KNP during January 1991 to April 1994. Their positions were recorded to the nearest $1.25^{\prime}$-quadrat of latitude and longitude (approximately $2 \times 2 \mathrm{~km}$ ). This is the finest scale at which most associated habitat information has been recorded within the numbered grid system adopted by the KNP authorities. These sightings were entered onto a spreadsheet (Quattro Pro 4.0, Borland International, Scotts Valley, Calif.), in which format they were compatible with data on vegetation structure which had been collected at the $2.5^{\prime}$-quadrat scale (i.e. approximately $4 \times 4 \mathrm{~km}$, incorporating four $1.25^{\prime}$-quadrats) (Kemp et al. 1997).

Comparative sight records of the Southern Ground Hornbill were also available from the systematic annual aerial census of the KNP performed during 1982-1994 (Joubert and Viljoen 1988, Kemp et al. 1989). More comprehensive searches for nest sites of ground hornbills were also available for the period 1966-1994 (Kemp and Begg 1996). Both data sets were from more systematic, 
prolonged and intensive searches and so provided a control for the random sightings of hornbills and their nests made during our 1991-1994 study.

The following categories of vegetation structure were recorded during 19911992 , by subjective visual assessment of all but 48 of the $10932.5^{\prime}$-quadrats that cover the KNP (Kemp et al. 1997).

Woody vegetation. Percentages of quadrat area, to the nearest $5 \%$, dominated by broad-leaved Combretum-Terminalia woodland, mopane Colophospermum mopane woodland, fine-leaved Acacia-Albizzia-Dicrostachys woodland, mixed woodland, riparian woodland or open areas lacking woody vegetation. Within each woody vegetation category, the percentages of scrub ( $<2 \mathrm{~m}$ high), bushes (2-4 $\mathrm{m}$ high) or trees $(>4 \mathrm{~m}$ high) were also estimated to the nearest $5 \%$. From the latter data it was possible to estimate the overall percentage of scrub, bush and tree cover for each quadrat, independent of the type of woody cover.

Ground cover. Grass (and forb) cover was estimated as present (o-25\%), occasional $(26-50 \%)$, frequent $(51-75 \%)$ or extensive $(76-100 \%)$. Small patches that lacked grass cover were categorized as present, occasional, frequent or extensive. Areas of extensive open patches, greater than $100 \mathrm{~m}^{2}$ and lacking any ground cover, were also noted as present or absent.

Emergent large trees. Presence of emergent baobab Adansonia digitata trees was recorded, and abundance of emergent live and dead trees was classed on a scale of $0-5$ ( $0=$ no emergent trees, $1=1-50$ trees, $2=51-100,3=101-200,4=201-$ $400,5=>401$ ).

We also recorded some topographic features that could be compared with existing maps as a cross-check on our procedures. These included the percentage of quadrat area classified as flat, undulating (with highest points of equivalent altitude), hilly (with some high points well above others), watercourse depressions, rocky outcrops, or rock cliffs.

All localities recorded for each bird species were plotted as $1.25^{\prime}$-quadrats on a map of the KNP, using the ARC/INFO GIS system (version 6.I.I, Environmental Systems Research Institute, Redlands, Calif.). These distribution maps were then compared with various categories of vegetation structure in $2.5^{\prime}$-quadrats, using the overlay features of the GIS.

Quadrat localities recorded for each bird species were compared first with individual categories of vegetation structure, such as "bush cover 10-30\%", and then with various combinations of vegetation categories, such as "tree cover 15$45 \%$ plus bare ground present and occasional". Vegetation categories that had the highest positive correlation with distribution records for each bird species and its nests were then selected.

This GIS correlation provided two results. (1) The distribution and percentage of the 1093 quadrats in the KNP that were covered by a particular vegetation category indicated where and how extensive that vegetation category was within the KNP. (2) The percentage of sightings for each bird species or its nests that overlapped with that vegetation category. The ratio of these percentages indicated where the correlation of bird/nest sightings with vegetation category departed from random (or a 1 : I ratio). This provided a measure of how well the vegetation category correlated with, or predicted, the presence of each bird species or its nests. The GIS overlay features also allowed visual comparison of 
the congruence between the distribution of bird sightings and vegetation categories.

\section{Results}

Almost all of the $10932.5^{\prime}$-quadrats in the KNP were visited at least once during the study period, if only to record vegetation structure (only 48 quadrats, mainly overlapping the borders of the KNP, were not visited, Kemp et al. 1997). However, some quadrats were visited much more often than others in the course of other projects and general travel. This produced an obvious bias in the distribution of the combined total of 659 random sightings that were obtained for the four species during the 1991-1994 study (Figure 1). For example, there are more records along certain roads and in certain areas, and there are also more records from north of the Olifants River (c. $24^{\circ} \mathrm{S}$ ). These biases were not evident for the systematic aerial census data, nor for records of nest sites which we searched for more systematically and for which we received reports from other observers (Table 1).

However, the distribution of sightings for individual species differed within this overall coverage (Figures 2-5), suggesting that there were specific differences in distribution and vegetation preference. The systematic aerial census data provided a much wider and more even coverage of sightings for the Southern Ground Hornbill (Figures $5 \mathrm{~b}$ and 6), except for the two hilly areas in the extreme north-west and south-west of the KNP which were not usually included in the coverage.

Several categories of vegetation structure had a positive correlation with the distribution of sightings for each bird species or its nests (Tables 2-5). The overlays which gave the most positive and predictive correlation, based on vegetation specificity, on bird use, on visual matching or on a combination of these indices, are mapped for each species (Figures 2-5). Where informative, correlations that best fitted records north of the Olifants River (c. $24^{\circ} \mathrm{S}$, mainly mopane habitat) and south of the river (mainly mixed woodland) were plotted separately, as for Martial Eagle (Figure 3).

For the Southern Ground Hornbill, vegetation categories that had the highest correlation with the distribution of random sightings of birds and nests from our 1991-1994 study were also compared with the aerial census data and with the larger sample of nest sites recorded between 1966 and 1996 (Table 5, Figure 5). The sum total of hornbills sighted within each quadrat, for all aerial censuses between 1982 and 1994, was also used for analysis (Table 6, Figure 6).

\section{Discussion}

General knowledge of large birds studied in the KNP suggested that it would be possible to record all four species anywhere in the KNP at some time or another. Large aerial species, such as the Martial Eagle and Lappet-faced Vulture, cover areas of over $100 \mathrm{~km}^{2}$ during just one day of foraging (A.C.K. and K.S.B. unpublished). Adult breeding pairs of eagles held territories of about $150 \mathrm{~km}^{2}$ (Kemp and Kemp 1974, van Zyl 1992, A.C.K. and K.S.B. unpublished), apparently spread throughout the $\mathrm{KNP}$, but non-breeders and immatures are 


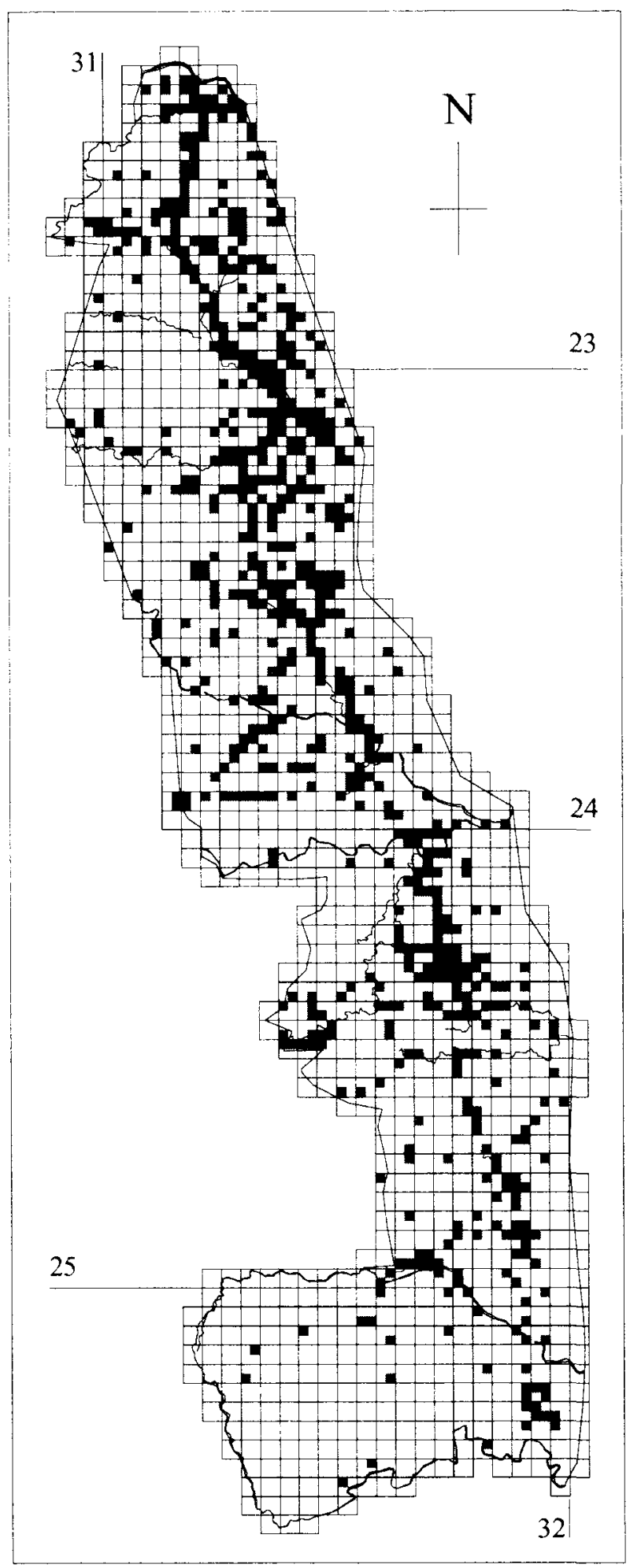

Figure 1. The combined distribution, plotted as $1.25^{\prime}$ quadrats, for sightings of Kori Bustard, Martial Eagle, Lappet-faced Vulture and Southern Ground Hornbill from the Kruger National Park (KNP) during January 1991-March 1994 (cf. Table 1). 
Table 1. Total number of $2.5^{\prime}$-quadrats in which four species of large bird were sighted in the Kruger National Park (KNP) for 1991-1994 (plotted by the 1.25' quadrats in which they were recorded) and the percentage of $2.5^{\prime}$ quadrats in which they were recorded north of the Olifants River

\begin{tabular}{lcc}
\hline Data & $n$ & $\%$ N of Olifants River \\
\hline Quadrats & 1093 & 52 \\
LARGE BIRD SIGHTINGS, 1991-1994 & & \\
Kori Bustard & 101 & 64 \\
Martial Eagle & 196 & 68 \\
Lappet-faced Vulture & 242 & 69 \\
Southern Ground Hornbill & 178 & 69 \\
LARGE BIRD NESTS, 1991-1994 & & \\
Lappet-faced Vulture nests & 60 & 25 \\
Southern Ground Hornbill nests & 30 & 34 \\
& & \\
SOUTHERN GROUND HORNBILLS CONTROLS & 666 & 56 \\
Hornbill aerial census (82-94) & 74 & 47 \\
Hornbill nests (66-96) & & \\
\hline
\end{tabular}

more nomadic. The vultures have a more clumped distribution of nest sites (Tarboton et al. 1980, Tarboton and Allan 1984), and probably also of roost and feeding areas, but they range widely for food, especially immatures (A.C.K. and K.S.B. unpublished).

The Southern Ground $\mathrm{F}_{2}$, smbill and Kori Bustard are much more terrestrial. Almost the entire population of the hormbill is sedentary and breeds within adjacent territories spread across the KNP (Kemp 1988, Kemp et al. 1989, Kemp and Begg 1996). The bustard is more patchily distributed and non-territorial, even partly social when gathering at communal roosts (A.C.K. and K.S.B. unpublished). It is also more nomadic and is suspected to perform extensive but poorly understood movements within southern Africa (Harrison et al. 1997).

It is not surprising, therefore, that none of the species appeared to have particular vegetation preferences within the KNP (Tables 2-5). The degree to which vegetation could be used to predict their distribution differed between the four species. These differences probably arose from three main factors: (1) the suitability of vegetation categories chosen for the assessment, with respect to the biology of each species; (2) variation between species in their habits, recordability and vegetation specificity, for example, the higher predictability of terrestrial (bustard, hornbill) versus aerial species (eagle, vulture); and (3) the extent that our coverage was truly random for the range of each species, for example, in accounting for basic vegetation differences north and south of the Olifants River.

Vegetation categories in which species were most frequently recorded presumably indicated either the habitat preference of that species or where a species would be relatively most abundant. However, the comparison of hornbill numbers recorded from the aerial census data (Table 6) suggested that vegetation preference did not correlate well with relative abundance. The predictions offered by our results can be tested by visits to areas of different habitats in which the species was not recorded during our study, or by use of alternative survey methods. The use of vegetation categories to predict areas in which each 


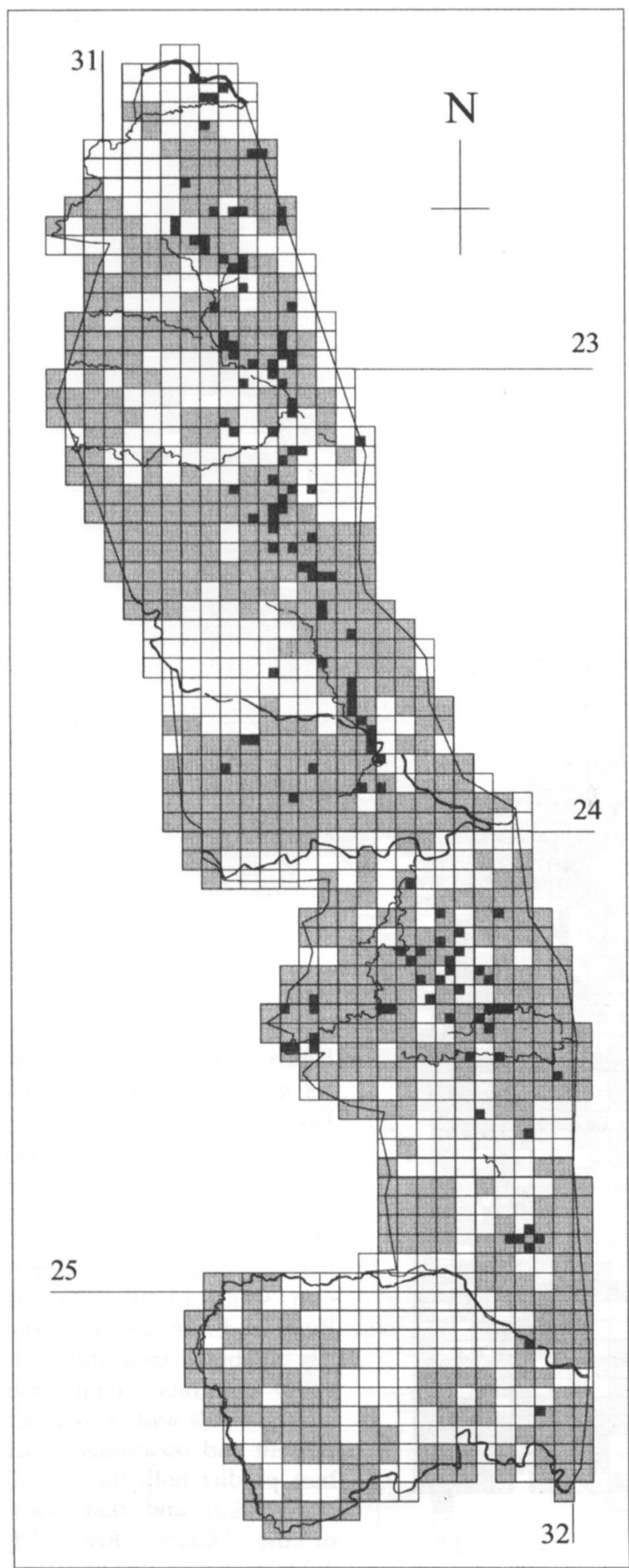

Figure 2. The distribution of $1012.5^{\prime}$ quadrats in which Kori Bustards were recorded during 1991-1994 in the KNP, together with the extent of the 619 combined vegetation quadrats that best predict that distribution, "total bush $<50 \%$ and bare areas present and occasional" (cf. Table 2). 


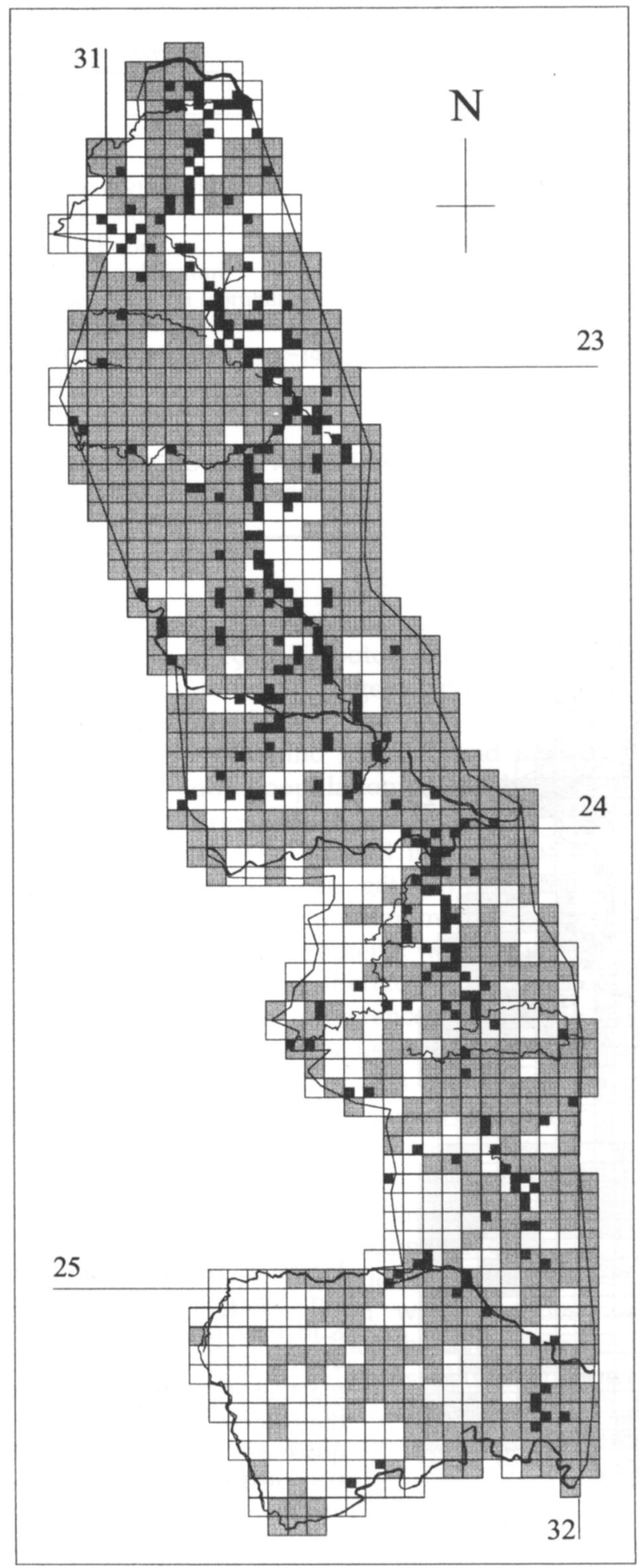

(a)

Figure 3. Distribution of 196 2.5' quadrats in which Martial Eagles were recorded during 1991-1994 in the KNP, together with $(a)$ the extent of the 547 vegetation quadrats, "total bush cover 15-50\%", that best predict that distribution south of the Olifants River and, (b) (see p 97) the 583 combined vegetation category quadrats, "total bush cover $15-50 \%$ and grass cover present and occasional", that best predict both the overall distribution and that north of the Olifants River (cf. Table 3). 


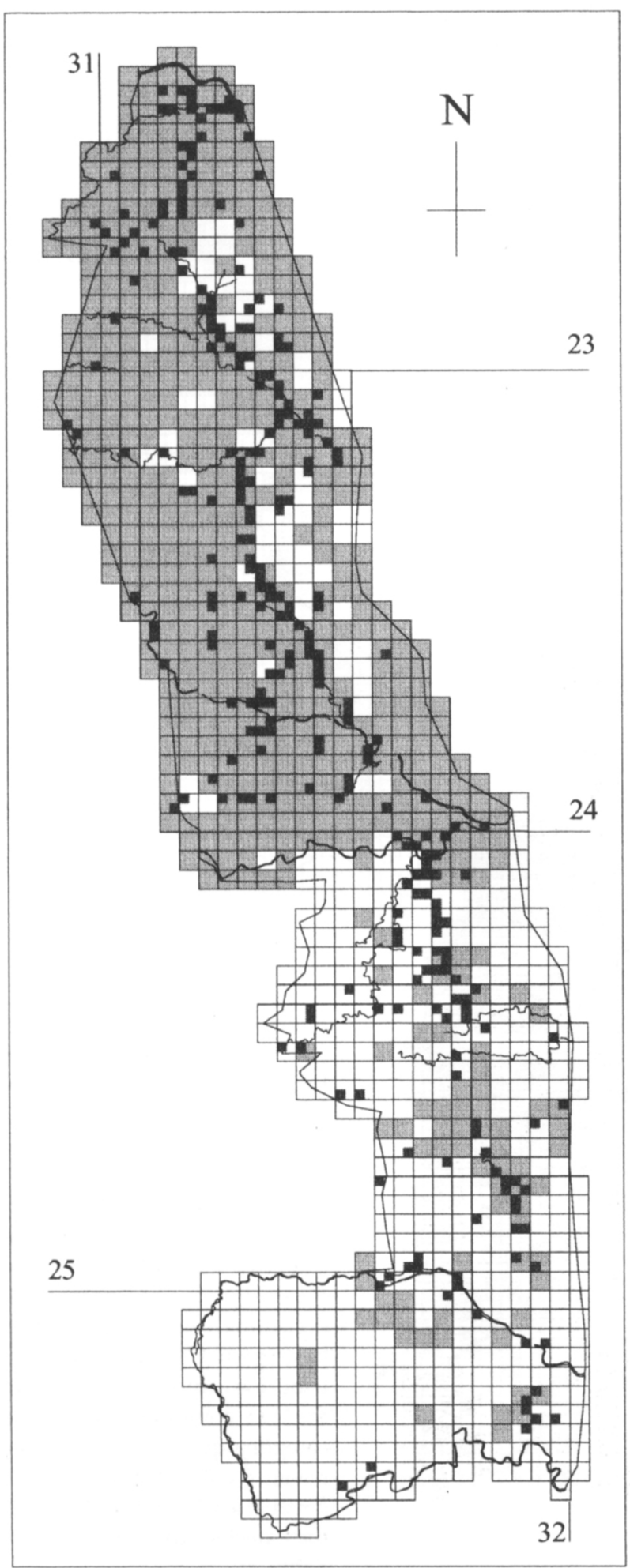

(b) 


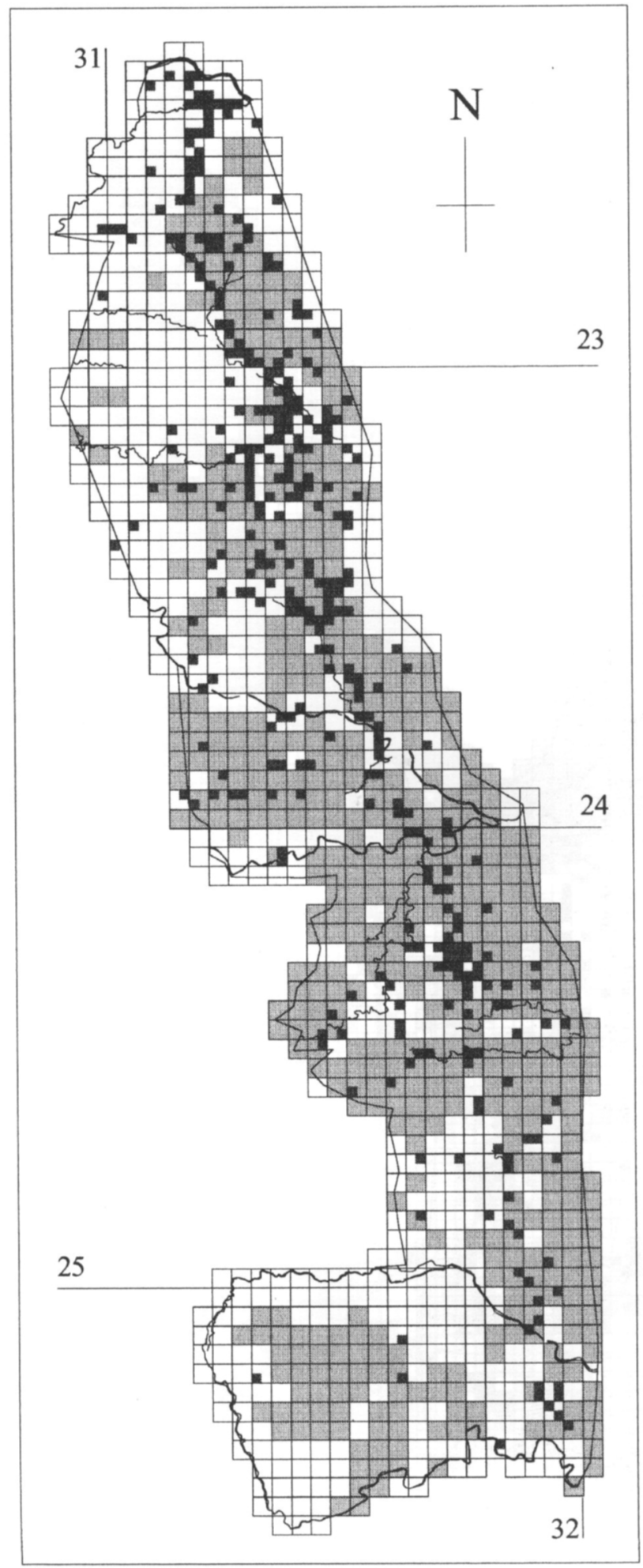

(a)

Figure 4. Distribution of $(a)$ $242 \quad 2.5^{\prime}$ quadrats in which Lappet-faced Vultures and $(b)$ 60 quadrats in which their nests were recorded during 1991-1994 in the KNP, together with the extent of $(a)$ the 530 combined vegetation category quadrats, "total tree cover $<5.5 \%$ and grass cover occasional and frequent", that best predict the vulture's distribution, and (b) (see p 99) the 222 combined vegetation category quadrats, "total tree cover $<3.5 \%$ and total bush cover $<40 \% "$, that best predict the nest's distribution (cf. Table 4). 


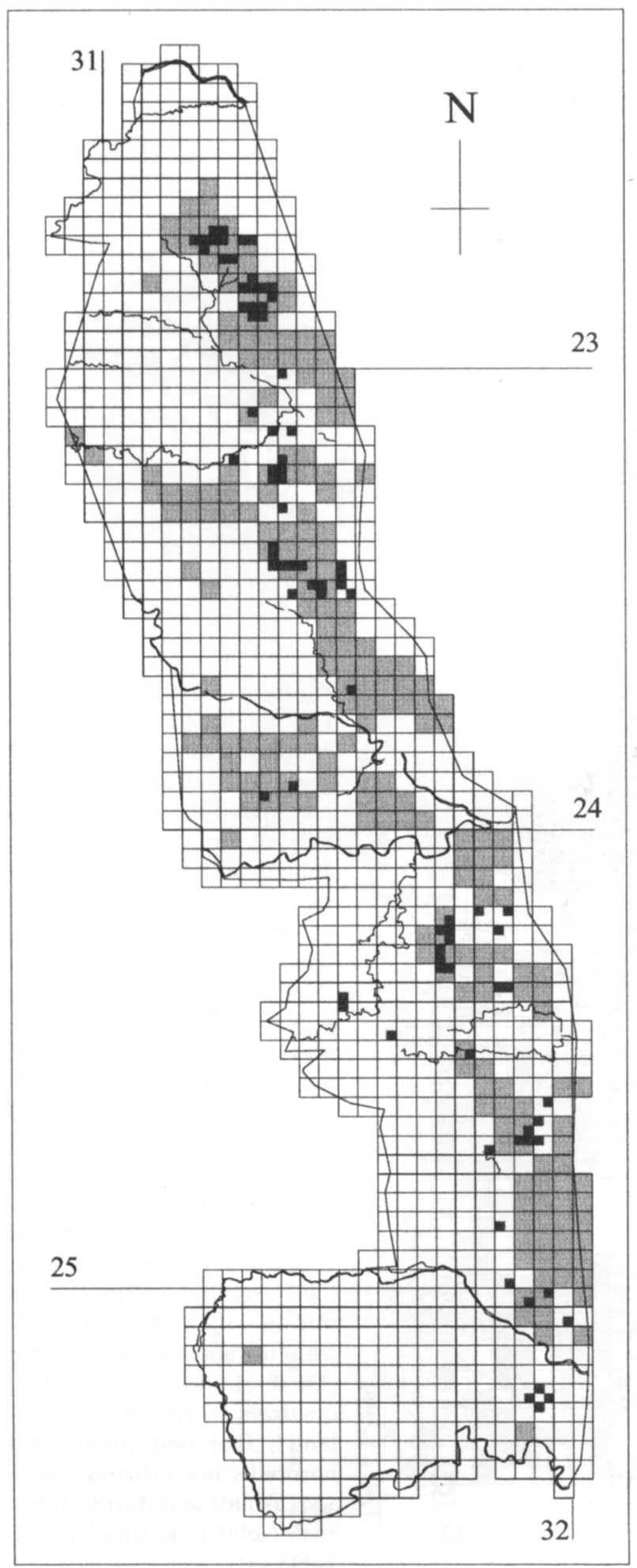

(b) 


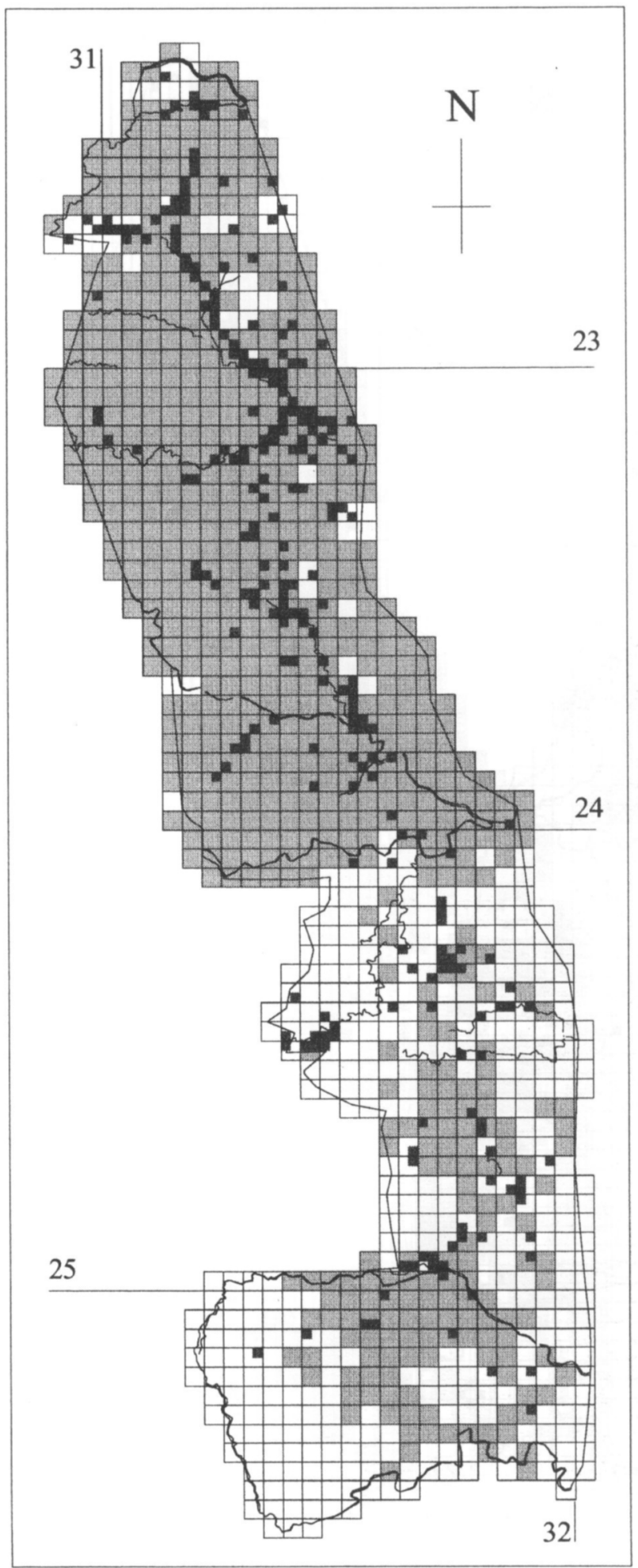

(a)

Figure 5. Distribution of (a) $178 \quad 2.5^{\prime}$ quadrats in which Southern Ground Hornbill groups, (b) (see p 101) 666 $1.25^{\prime}$ quadrats in which hornbills were recorded from annual aerial census during 1982-1994, and (c) (see p 102) $30 \quad 1.25^{\prime}$ quadrats (black) in which their nests were recorded during 1991-1994 plus 73 1.25' quadrats (dark grey) in which nests were found during 1966-1996 in the KNP. Also shown is the extent of the 574 combined vegetation category quadrats, "total scrub cover $10-40 \%$ and grass cover present and occasional", that best predict the hornbill's distribution (a) during 1991-1994 and (b) from the aerial census. (c) The extent of the 347 vegetation quadrats, "riparian woodland", that best predict the hornbill's nests during 19911994 (solid) and during 19661996 (solid plus stippled) (cf. Table 5). 


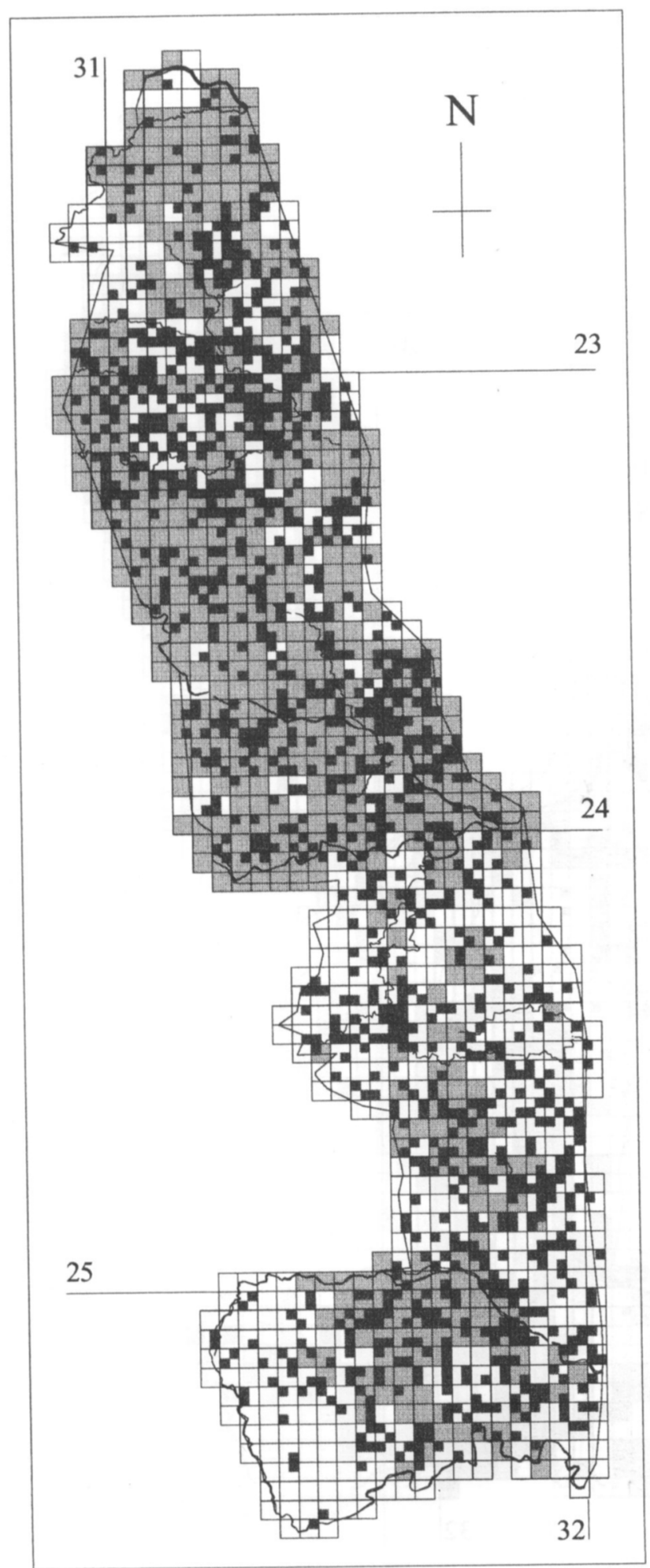

(b) 


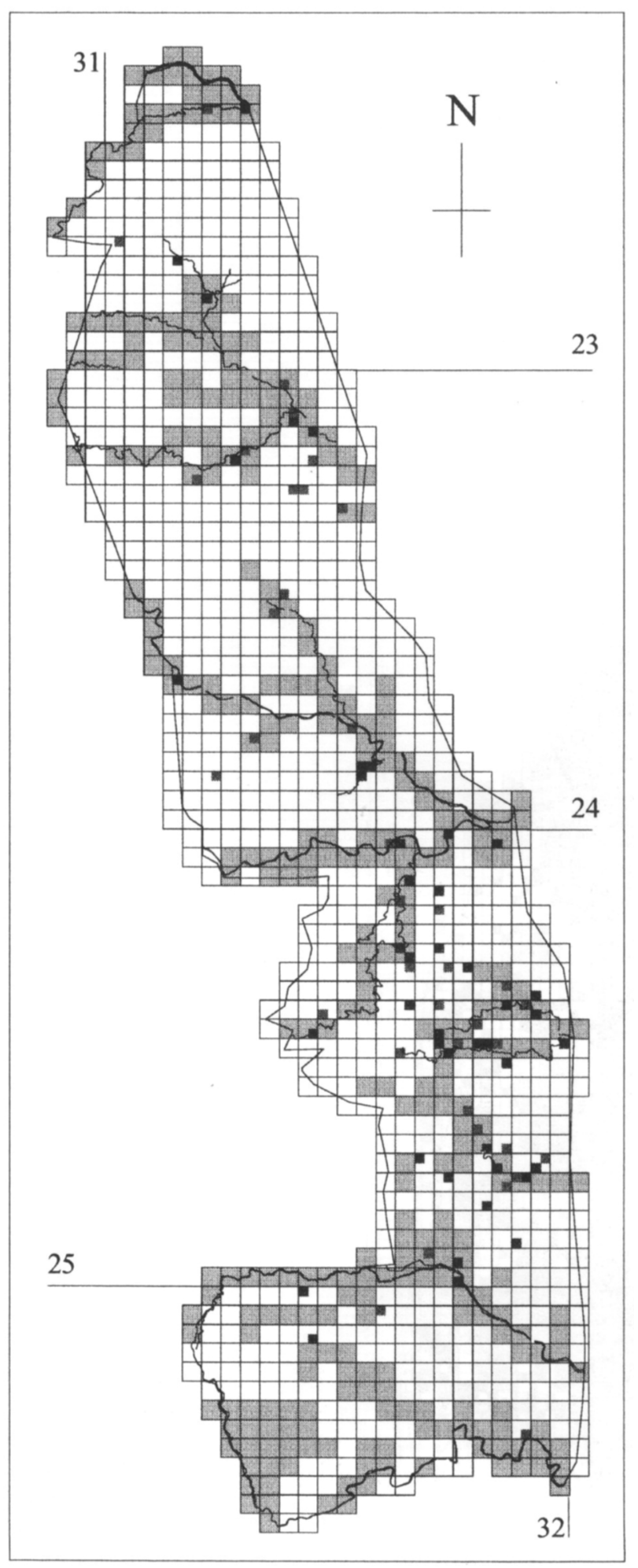

(c) 


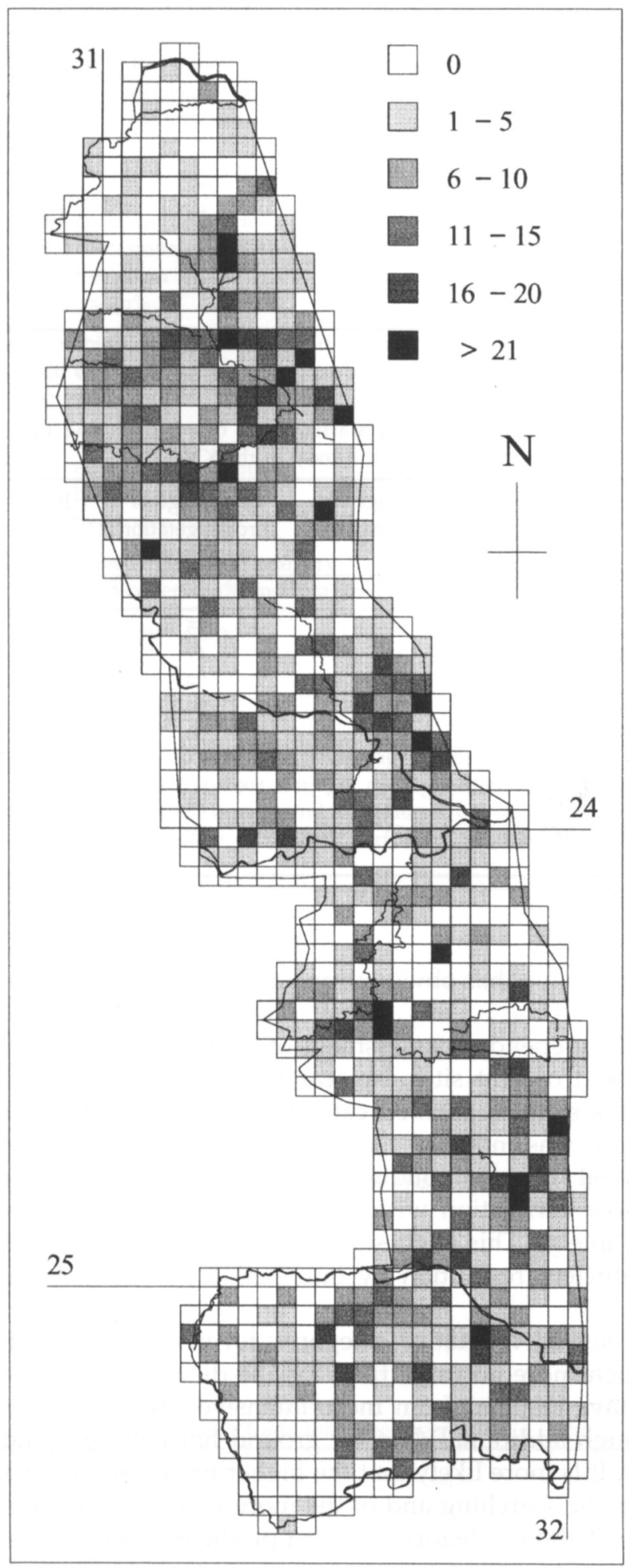

Figure 6. Total number of Southern Ground Hornbills counted per $2.5^{\prime}$ quadrat from the annual aerial census during 1982-1994, as an index of relative abundance in the KNP (cf. Tables 5 and 6). 
Table 2. Highest percentage overlap for random sightings of Kori Bustard $(n=101)$ during $1991-1994$ with various vegetation categories within $2.5^{\prime}$ quadrats $(n=1093)$ in the KNP

\begin{tabular}{lccc}
\hline Vegetation categories & $\begin{array}{c}\text { Percentage of } \\
\text { KNP area (A) }\end{array}$ & $\begin{array}{c}\text { Percentage of } \\
\text { bird/vegetation } \\
\text { overlap (B) }\end{array}$ & B/A \\
\hline $\begin{array}{l}\text { Single vegetation categories } \\
\text { Bare areas, present \& occasional }\end{array}$ & 64 & 75 & 1.17 \\
$\quad$ Total bush cover <50\% & 69 & 87 & 1.26 \\
Best combined vegetation category & & 70 & 1.49 \\
$\quad \begin{array}{l}\text { Total bush cover <50\% and bare areas, } \\
\text { present and occasional }\end{array}$ & 47 & & \\
\hline
\end{tabular}

"Plotted as Figure 2.

Table 3. Highest percentage overlap for random sightings of Martial Eagle $(n=196)$ during 19911994 with various vegetation categories within $2.5^{\prime}$ quadrats $(n=1093)$ in the KNP

\begin{tabular}{lccc}
\hline Vegetation categories & $\begin{array}{c}\text { Percentage of } \\
\text { KNP area (A) }\end{array}$ & $\begin{array}{c}\text { Percentage of } \\
\text { bird/vegetation } \\
\text { overlap (B) }\end{array}$ & B/A \\
\hline $\begin{array}{l}\text { Single vegetation categories } \\
\text { Total Quadrats bush cover 15-50\% }\end{array}$ & 66 & 75 & 1.02 \\
S. Olifants R." & 49 & 17 & 1.45 \\
Total scrub cover 10-35\% & 67 & 69 & 1.03 \\
Grass, present \& occasional & 66 & 79 & 1.20 \\
Open >20\% & 59 & 76 & 1.29 \\
Best combined vegetation category & & 72 & 1.31 \\
Open >20\% and grass present \& occasional & 55 & 70 & 1.32 \\
Total bush cover 15-50\% and grass present \& & 53 & & \\
occasional & & & \\
\hline
\end{tabular}

"Plotted as Figure $3 a, b$.

species and its nests are most prevalent has obvious applications for conservation management.

It was encouraging that the independent assessment of hornbill distribution, by the annual aerial census, and of nest sites, by searching over many years, were both best predicted by the same vegetation categories that applied to our short-term study. However, it was notable that vegetation categories that correlated best with the aerial census, conducted during the dry winter non-breeding season, had a low correlation with the distribution of nest sites, which are used in summer (Table 5). This suggests both seasonal differences in vegetation preference and sufficient resolution by our methods to distinguish such differences.

The ability to predict the preferred vegetation categories for nest sites, of both vulture and hornbill, was much more accurate than for the distribution of the birds themselves. This may have resulted from more intensive coverage when searching for nest sites, although additional data for ground hornbill nests did not improve the predictability. It is more likely that the higher predictability was a product of both more systematic searching and of the more specific vegetation requirements for nest sites. The habitat category that best predicted hornbill nest 
Table 4. Highest percentage overlap for random sightings of Lappet-faced Vulture $(n=242)$ or their nests $(n=60)$ during $1991-1994$ with various vegetation categories within $2.5^{\prime}$ quadrats $(n=1093)$ in the KNP

\begin{tabular}{lccc}
\hline Vegetation categories & $\begin{array}{c}\text { Percentage of } \\
\text { KNP area (A) }\end{array}$ & $\begin{array}{c}\text { Percentage of } \\
\text { bird/nest vegetation } \\
\text { overlap (B) }\end{array}$ \\
\hline
\end{tabular}

Vultures

Single vegetation categories

Grass, occasional and frequent

Total tree cover $<5.5 \%$

Open 15-40\%

$\begin{array}{lll}80 & 80 & 1.00 \\ 61 & 70 & 1.15 \\ 63 & 76 & 1.21\end{array}$

Best combined vegetation category

Total tree cover $<5.5 \%$ and grass occasional and

frequent $t^{2}$

Nests

Single vegetation categories

Total bush cover $<40 \%$

Total tree cover $<3.5 \%$

$\begin{array}{lll}40 & 70 & 1.75 \\ 4^{2} & 75 & 1.7^{2}\end{array}$

Best combined vegetation category

Total bush cover $<40 \%$ and total tree cover $<3.5 \%{ }^{a}$

20

57

2.85

"Plotted as Figure $4 \mathrm{a}, \mathrm{b}$.

Table 5. Comparison of highest percentage overlap for sightings of Southern Ground Hornbill groups made at random (1991-1994, $n=178$ ), during systematic aerial censuses ( $>5$ sightings/quadrat, 19821994, $n=314)$, of their nests found at random (1991-1994, $n=37)$, and of nests found during extended searching (1966-1996, $n=73$ ), with various vegetation categories within $2.5^{\prime}$ quadrats $(n=1093)$ in the KNP

\begin{tabular}{lll}
\hline Vegetation categories & $\begin{array}{c}\text { Percentage of } \\
\text { KNP area (A) }\end{array}$ & $\begin{array}{c}\text { Percentage of } \\
\text { bird/nest vegetation } \\
\text { overlap (B) }\end{array}$ \\
\hline
\end{tabular}

HORNBILLS, RANDOM (AERLAL >5)

Single vegetation categories

Total scrub cover $10-40 \%$

Total bush cover $<50 \%$

$\begin{array}{lll}80 & 76(73) & 0.95(0.91) \\ 69 & 75(73) & 1.09(1.06) \\ 75 & 73(72) & 0.97(0.96)\end{array}$

Total tree $>2 \%$

53

$60(56)$

$1.13(1.06)$

Total scrub $10-40 \%$ and grass present and occasional" $^{\prime \prime}$

NESTS, 1991-1994 (1966-1996)

Single vegetation categories

Total tree cover $1-7.5 \%$

Live trees $>2 \%$

Riparian $>0.1 \%$

\begin{tabular}{lll}
62 & $70(70)$ & $1.13(1.13)$ \\
67 & $78(78)$ & $1.16(1.16)$ \\
34 & $54(56)$ & $1.59(1.65)$ \\
64 & & \\
& $57(45)$ & $0.89(0.70)$ \\
\hline
\end{tabular}

Best combined vegetation category

Total scrub cover $10-40 \%$ and total tree cover $>2 \%$

a Plotted as Figure 5a-c. 
Table 6. Percentage overlap between total numbers of Southern Ground Hornbills counted per 2.5' quadrat within the KNP during 14 annual aerial censuses (1982-1994) and combined vegetation categories for quadrats of (a) total scrub cover $10-40 \%$ and grass present plus occasional $(\mathrm{p}+0 ; n=574)$, and (b) total scrub cover $10-40 \%$ and total tree cover $>2 \%(n=669)$

\begin{tabular}{|c|c|c|c|}
\hline \multirow{2}{*}{$\begin{array}{l}\text { Total number of } \\
\text { Southern Ground } \\
\text { Hornbills counted } \\
\text { per } 2.5^{\prime} \text { quadrat }\end{array}$} & \multirow[t]{2}{*}{$n$} & \multicolumn{2}{|c|}{ Percentage overlap } \\
\hline & & $\begin{array}{l}\text { (a) scrub } 10-40 \% \\
\text { and grass } p+o\end{array}$ & $\begin{array}{c}\text { (b) scrub } 10-40 \% \\
\text { and tree }>2 \%\end{array}$ \\
\hline $1+$ & 666 & 56 & 62 \\
\hline $2+$ & 636 & 57 & 63 \\
\hline $3+$ & 568 & 60 & 62 \\
\hline $4^{+}$ & 475 & 56 & 60 \\
\hline $5^{+}$ & 384 & 55 & 60 \\
\hline $6+$ & 314 & 57 & 62 \\
\hline $7^{+}$ & 261 & 59 & 61 \\
\hline $8+$ & 229 & 58 & 60 \\
\hline $9+$ & 195 & 60 & 59 \\
\hline IO+ & 164 & 57 & 60 \\
\hline I1t & 137 & 55 & 59 \\
\hline $12+$ & 104 & 59 & 58 \\
\hline $13^{+}$ & 84 & 54 & 54 \\
\hline $14+$ & $7^{2}$ & 56 & 54 \\
\hline $15^{+}$ & 60 & 52 & 52 \\
\hline
\end{tabular}

sites using the GIS, i.e. "riparian woodland", was also equivalent to the $54 \%$ of nest sites classified as "along drainage lines" by local assessment (Kemp and Begg 1996). It again indicates that the GIS method is of sufficient resolution to be useful for conservation management.

The use of correlations between our vegetation categories and sightings to predict bird distribution and habitat has already been applied to smaller birds and at smaller scales (Hurford et al. 1996). This study suggests that the method is also feasible for large bird species, on a scale sufficiently large to incorporate their extensive biology and to cover major conservation areas. It suggests further that vegetation associations of widespread species can be predicted and incorporated into management plans using relatively simple methodology. The method was facilitated by the use of GIS and by making rapid subjective visual assessment of vegetation categories. Its accuracy will differ between species, depending on their biology and on the habitat categories selected, and is expected to be most accurate for nest sites.

\section{Acknowledgements}

We appreciate the support of all field staff while working in their areas of influence within the KNP and especially the assistance and encouragement of Messrs Ian Whyte, Louis Olivier and Scott Ronaldson, and Drs Salomon Joubert, Willem Gertenbach, Douw Grobler and Petri Viljoen. Assistance in the design of data sheets and GIS analysis was provided by Dr Amanda Lombard and Ms Jean Hurford. The project was sponsored by The Southern Life Association and administered by the FitzPatrick Institute, University of Cape Town. We wish to thank Mr Quentin Pretorius and Prof. Roy Siegfried for their support. 


\section{References}

Gertenbach, W. P. D. (1980) Rainfall patterns in the Kruger National Park. Koedoe 23: $35-43$.

Gertenbach, W. P. D. (1983) Landscapes of the Kruger National Park. Koedoe 26: 9-122.

Harrison, J. A., Allan, D. G., Underhill, L. G., Herremans, A. J., Tree, A. J., Parker, V. and Brown, C. J. (1997) The atlas of southern African birds,I. Non-passerines. Cape Town: Birdlife South Africa and Avian Demographic Unit.

Hurford, J. L., Lombard, A. D., Kemp, A. C. and Benn, G. A. (1996) Geographical analysis of six rare bird species in the Kruger National Park, South Africa. Bird Conserv. Internatn. 6: $133-153$.

Joubert, S. C. J. and Viljoen, P. C. (1988) Ecological aerial monitoring in the Kruger National Park. S. Afr. Natn. Sci. Prog. Rep. 157: 308-315.

Kemp, A. C. (1988) The behavioural ecology of the southern ground hornbill: are competitive offspring at a premium? Pp. $267-271$ in R. van den Elzen, K.-L. Schuchmann and K. Schmidt-Koenig, eds. Current topics in avian biology. Bonn: Proc. Internatn.-10o Deutscheornitologische-Gesellschaft Meeting.

Kemp, A. C. (1992) Wanderers in search of wild places. Getaway February 1992: 66-67.

Kemp. A. C. and Begg, K. S. (1996) Nest sites of the Southern Ground Hornbill Bucorous leadbeateri in the Kruger National Park, South Africa, and conservation implications. Ostrich 67: 9-14.

Kemp, A. C. and Kemp, M. I. (1974) Don't forget the big birds. Afr. Wildl. 28: 12-13.

Kemp, A. C. and Kemp, M. I. (1980) The biology of the Southern Ground Hornbill Bucorvus leadbeateri (Vigors) (Aves: Bucerotidae). Ann. Transvaal Mus. 32: 65-100.

Kemp, A. C., Joubert, S. C. J. and Kemp, M. I. (1989) Distribution of southern ground hornbills in the Kruger National Park in relation to some environmental factors. $S$. Afr. J. Wildl. Res. 19: 93-98.

Kemp, A., Chadwick, P. and Begg, K. (1991) Kruger Park's rarer bird species studied. Custos 20(7): 12-15.

Kemp, A. C., Begg, K. S., Benn, G. A. and Chadwick, P. (1997) A visual assessment of vegetation structure for the Kruger National Park. Koedoe 40 (2): 117-121.

May, R. M. (1994) The effects of spatial scale on ecological questions and answers. Pp. 118 in P. J. Edwards, R. M. May and N. R. Webb, eds. Large-scale ecology and conservation biology. Oxford: Blackwell Scientific Publications.

Miller, R. I., Stuart, S. N. and Howell, K. M. (1989) A methodology for analysing rare species distribution patterns utilizing GIS technology: the rare birds of Tanzania. Landscape Ecol. 2: 173-189.

Tarboton, W. R. and Allan, D. G. (1984) The status and conservation of birds of prey in the Transvaal. Transvaal Mus. Monogr. 3: 1-115.

Tarboton, W. R., Kemp, M. I. and Kemp, A. C. (1980) Birds of the Transvaal. Pretoria: Transvaal Museum.

van Zyl, A. J. (1992) Do breeding pairs of Martial Eagles hold "super-normal" territories? Gabar 7: 9-10.

Watson, R. T. (1990) Population dynamics of the Bateleur in the Kruger National Park. Ostrich 61: 5-12.

\section{A. C. KEMP}

Department of Birds, Transvaal Museum, P. O, Box 413, Pretoria, ooo1 South Africa

FitzPatrick Institute, University of Cape Town, Rondebosch, 7700 South Africa. 
' Present address: Natal Parks Board, P. O. Box 662, Pietermaritzburg, 3200 South Africa.

${ }^{2}$ Present address: Honey Badger Project, Kalahari Gemsbok National Park, Private Bag X 5890 , Upington, 8803 South Africa. 